\title{
Phytochemicals Present in Cajanus cajan and its Use in Green Synthesis of Metal and Metal Oxide Nanoparticles
}

\author{
Shriniwas Pramod Patil*, Rajesh Yadav Chaudhari \\ Tapi Valley Education Society's Hon, Loknete Madhukarrao Chaudhari College of Pharmacy, Faizpur, Tal- Yawal, Dist-Jalgaon, Maharashtra, INDIA.
}

\begin{abstract}
Many attempts have been made for green synthesis of metal oxide nanoparticles; revealing the importance of plant extracts in reducing metal/ metal oxide precursor to nanoparticles and their applications in various scientific domains. Cajanus cajan (L.) Mill sp. (Pigeon pea), one of the pulses in human diet is legume plant, belonging to family Fabaceae or Papilionaceae. This plant has been reported to contain several phytochemicals like flavonoids glycosides, stilbenes. This article focus on applications of Cajanus cajan extract in fabrication of nanoparticles of various metals and metal oxides like silver, gold, titanium dioxide, zinc oxide. In respective research attempts, these nanoparticles were evaluated for one or more applications like anti-microbial activity and/or photocatalytic activity. Use of polar extract of Cajanus cajan indicated involvement of its
\end{abstract}

polar phyto-compounds in reducing the metal source and stabilizing the nanoparticles.

Key words: Cajanus cajan, Phytochemicals, Nanoparticles, Anti-microbial activity, Photocatalytic activity.

\section{Correspondence}

Mr. Shriniwas Pramod Patil

Tapi Valley Education Society's Hon, Loknete Madhukarrao Chaudhari College of Pharmacy, Faizpur, Yawal, Jalgaon, Maharashtra, INDIA.

Phone no: +919561245170

Email: patilsp111@gmail.com

DOI: 10.5530/jpi.2021.1.1

\section{INTRODUCTION}

Nanotechnology and its products are gaining vast attention of huge number of researchers due to their tremendous applications in various scientific domains. One of such wonderful nano-product is nanoparticles of metals and metal oxides. Due to wide range of utilities, several strategies have been developed for the fabrication of these nanoparticles. Increasing demand of green route of its synthesis, leads to simple way of addition of herbal extract to metal precursor solution. As this technique uses herbal extract, naturally, available phytochemicals have been found responsible for reduction of precursor to aggregation of metal ions, forming nanoparticles. These phytochemicals can be primary or secondary metabolites, which could be very specific to the plant and its organ selected for extraction. Several plants in several attempts have been found successful in reduction-based synthesis of nanoparticles of selected metal or metal oxide. ${ }^{1}$ This review summarizes, the use of Cajanus cajan in green synthesis of various metal and metal oxide nanoparticles.

Cajanus cajan (L.) Mill sp. (Pigeon pea) (Figure 1), with edible seeds, is very important commercial legume crop belonging to family Fabaceae or Papilionaceae. This plant is adapted to the tropical and subtropical region and it can be grown with low fertilizer input on marginal land, even under drought condition. Genotype represents its determinate growth. It has deep tap root system which extends vertically and spread horizontally through lateral roots. Its stems are angular and woody. It has spirally arranged, pinnately trifoliate and lanceolate to oblong shaped terminal and lateral leaves, 4-17 cm in length and 3-15 mm long petiole. Due to the presence of simple or glandular hairs, leaves are pubescent. Its flowers are zygomorphic, bisexual and predominantly yellow coloured with acropetal orientation and raceme inflorescence. Pods are highly variable in size, bears 2-7 seeds.
Before exploring the uses of C. cajan in fabrication of nanoparticles, it will be worth noted that several phytochemicals of different classes have reported to be present in different parts of plant.

\section{Phytochemicals present in Cajunus cajan}

Like other plants, Cajanus cajan also produces several types of secondary metabolites. So far, many research reported the different phytochemicals belonging to different classes, mostly, flavonoids and stilbenes (Table 1; Figure 2). These phytochemicals may have beneficial role in C. cajan physiology. Here, several research articles and reviews published on isolation of any phytochemicals or phytochemical analysis of C. cajan have been referred.

Apart from these, terpenes mainly present in essential oils obtained from C. cajan leaves, seeds and stem have also been reported. These includes caryophyllene, $\alpha$-calacorene, trans-nerolidol, $\delta$-cadinene, $a$-selinene $\beta$-himachalene, $\beta$-bisabolene, $\alpha$-Humulene allo-aromadendrene, $\gamma$-muurolene, $\gamma$-Himachalene, $\beta$-selinene, $\alpha$-himachalene, longifolene, $\alpha$-gurjunene, dodecanal, $\beta$-caryophyllene, $\beta$-cedrene, $\beta$-duprezianene, $\beta$-gurjunene, trans- $\alpha$-bergamotene, $\alpha$-guaiene, $\alpha$-longipinene, cyclosativene, $\alpha$-copaene, caryophyllenyl alcohol, himachalene epoxide, caryophyllene oxide etc. ${ }^{12}$

\section{CAJANUS CAJAN ASSISTED SYNTHESIS OF NANOPARTICLES}

So far, few research attempts were made for the synthesis of different metal and metal oxide nanoparticles using any part of Cajanus cajan. Usually, it involves simple addition of C. cajan extract to donor solution, characterisation of nanoparticles using advanced analytical techniques; and evaluation of these nanoparticles for suitable application in any 
Table 1: Phytochemicals present in different parts of $C$. cajan.

\begin{tabular}{|c|c|c|}
\hline Phytochemicals & Class & Reference \\
\hline \multicolumn{3}{|l|}{ Leaves } \\
\hline Cajanotone & \multirow{3}{*}{ Stilbenoids } & \\
\hline Cajanamide A & & \\
\hline Pinostrobin & & \\
\hline Naringenin 40,7-dimethyl ether & \multirow{2}{*}{ Dihydroflavones } & \\
\hline Naringenin 7-methyl ether & & \\
\hline \multicolumn{3}{|l|}{ 5,7-dihydroxy-8-prenylflavone } \\
\hline Cajaninstilbene acid & \multirow{6}{*}{ Ketones } & 2 \\
\hline \multicolumn{3}{|l|}{ Amorfrutin A } \\
\hline 3-methoxy-2-(3-methylbut-2-enyl)-5- & & \\
\hline (2-phenylethyl)phenol & & \\
\hline \multicolumn{2}{|l|}{ Pinosylvin monomethyl ether } & \\
\hline \multicolumn{2}{|l|}{ Longistylin A } & \\
\hline \multicolumn{2}{|l|}{ Longistylin C } & \\
\hline Apigenin & & 3 \\
\hline Vitexin & & \\
\hline Isovitexin & & 4 \\
\hline Luteolin & Flavone glycosides & 5 \\
\hline \multicolumn{3}{|l|}{ Orientin } \\
\hline $\begin{array}{l}\text { Apigenin- } 6,8-\mathrm{di}-\mathrm{c}-\mathrm{\alpha}-\mathrm{-}- \\
\text { arabinopyranoside }\end{array}$ & & 6 \\
\hline Biochanin a & Isoflavone & 7 \\
\hline Quercetin & Flavon & 3 \\
\hline \multicolumn{3}{|l|}{ Isorhamnetin } \\
\hline Cajanol & Isoflavanone & 7 \\
\hline Pinostrobin chalcone & \multirow{2}{*}{ Chalcone } & 8 \\
\hline Cajachalcone & & 9 \\
\hline Cajanstilbene $\mathrm{H}$ & Halogen- & \\
\hline & Containing Stilbene & 10 \\
\hline \multicolumn{3}{|l|}{ Seeds } \\
\hline \multirow[t]{2}{*}{ Quercetin-3-O-b-D-glucopyranoside } & Flavonoid-O- & \\
\hline & glycosides & \\
\hline Orientin & \multirow{2}{*}{$\begin{array}{c}\text { Flavonoid-C- } \\
\text { glycosides }\end{array}$} & \\
\hline Vitexin & & \\
\hline Quercetin & \multirow{4}{*}{ Flavonoid aglycones } & 11 \\
\hline Luteolin & & \\
\hline Apigenin & & \\
\hline Isorhamnetin & & \\
\hline
\end{tabular}

scientific domain. Here, research articles pertaining to synthesis of nanoparticles from any C. cajan extract have only been referred.

\section{Silver nanoparticles (Ag NPs)}

Silver nanoparticles have wonderful applications in various scientific domains like their antimicrobial action against various microbes, anticancer activity, photocatalytic potential etc. Understanding the significance of Ag NPs, Nagati et al. synthesised Ag NPs using C. cajan leaf extract. ${ }^{13}$ They prepared aqueous extract of $C$. cajan leaf; added it to

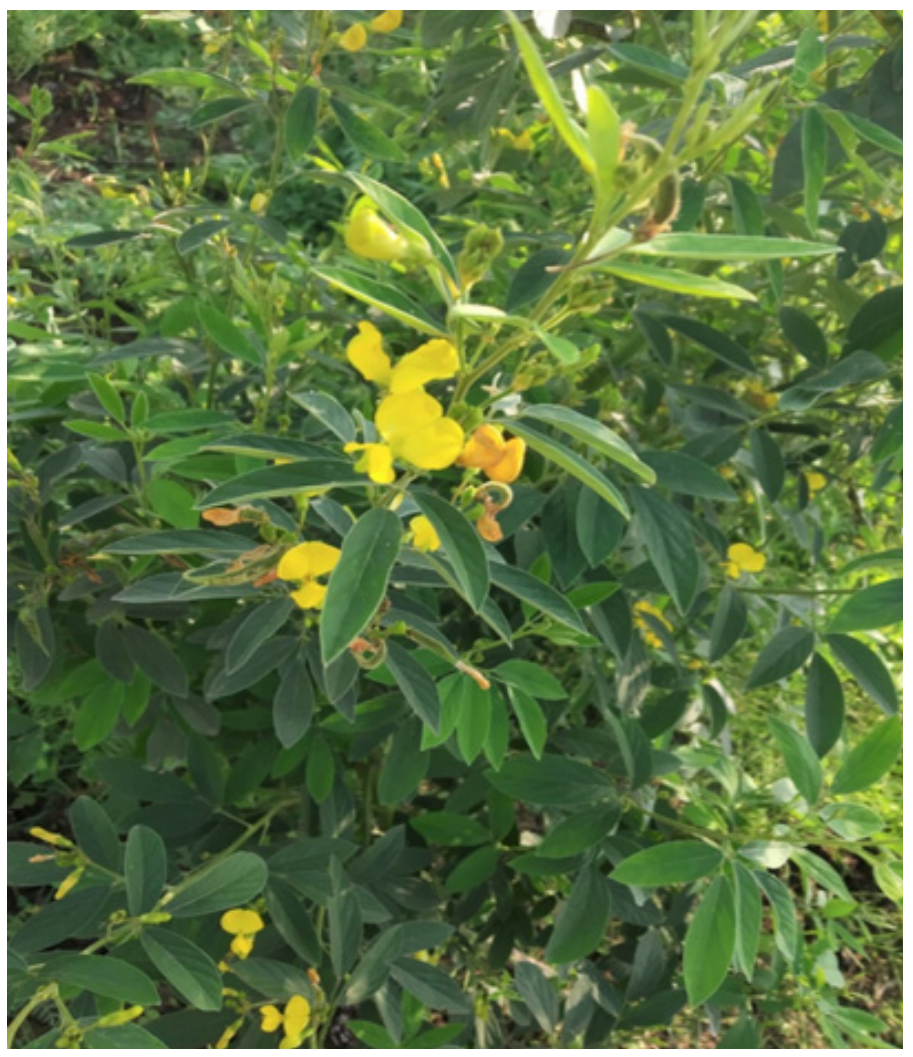

Figure 1: Cajanus cajan plant.

1) Cajanus cajan plant

2) Phytochemicals present in Cajanus cajan: 1, cajanotone; 2 , cajanamide A; 3, pinostrobin; 4, cajaninstilbene acid; 5, amorfrutin A; 6, longistylin A; 7, longistylin $\mathrm{C} ; 8$, cajanstilbene $\mathrm{H}$.

$1 \mathrm{mM}$ solution of silver nitrate aqueous solution and heated to $60^{\circ} \mathrm{C}$ for $15 \mathrm{~min}$. UV-Visible spectrum showed maximum absorption at $470 \mathrm{~nm}$, while FT-IR fingerprint revealed the functional groups of compounds present around the Ag NPs which includes compounds with aliphatic and aromatic amines, carboxylic acids. SEM analysis determined the size of these nanoparticles which was ranging between 5-60 nm while TEM showed that Ag NPs are spherical in shape. Further, researchers evaluated antimicrobial activity of Ag NPs against Staphylococcus aureus (Gram positive) and Escherichia coli (Gram negative) by disc diffusion assay method. The zone of inhibition exhibited by Ag Nps were found dose dependent and comparative to that with standard ampicillin.

\section{Zinc oxide nanoparticles (ZnO NPs)}

Zinc oxide is thermally and chemically stable, II-VI semiconductor having band gap of $3.37 \mathrm{eV}$. It has been studied thoroughly and used in solar cells, photo catalysts transistors, piezoelectric transducers and gas sensors. ${ }^{14}$ Considering these applications of zinc oxide, in 2014, Manjunath et al. attempted to develop facile method for preparation of high quality $\mathrm{ZnO}$ with uniform morphologies in the form of zinc oxide nanoparticles using C. cajan leaves powder. They mixed zinc nitrate and pigeon pea ground powder (1:1) and stirred for $10 \mathrm{~min}$ in double distilled water. The system was heated to $120^{\circ} \mathrm{C}$ for $1 \mathrm{hr}$ to get foamy mass which was then heated to $300^{\circ} \mathrm{C}$ to get gel. Smoldering of this gel further leads to formation of nano-crystalline $\mathrm{ZnO}$. This was calcinated at $400^{\circ} \mathrm{C}$ for $2 \mathrm{hr}$ to get ZnO NPs. Further, ZnO NPs were characterised using advanced techniques for determination of various properties, including powder X-ray diffraction (determined hexagonal zincite structure), FTIR spectral analysis (confirmed vibrational mode 
<smiles>COc1cc(O)cc(C(C)C(=O)c2ccccc2)c1CC=C(C)C</smiles><smiles>COc1cc(O)c2c(=O)[nH]c(-c3ccccc3)cc2c1CC=C(C)C</smiles><smiles>CCCCNc1c(OC)cc(/C=C/c2ccccc2)c(C(=O)O)c1O</smiles><smiles>COc1cc(O)c2c(c1)OC(c1ccccc1)CC2=O</smiles><smiles>COc1cc(CCc2ccccc2)c(C(=O)O)c(O)c1CC=C(C)C</smiles><smiles>CCCCCN(CC)c1c(O)cc(/C=C/c2ccccc2)cc1OC</smiles>

6<smiles>COc1cc(O)cc(/C=C/c2ccccc2)c1Br</smiles>

7

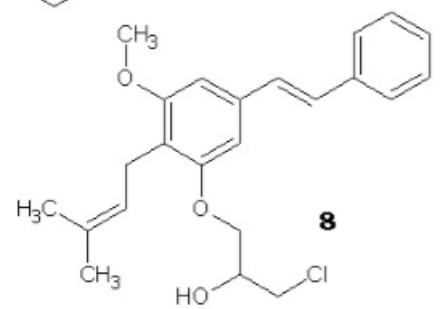

Figure 2: Phytochemicals present in Cajanus cajan: 1, cajanotone; 2 , cajanamide $A ; 3$, pinostrobin; 4, cajaninstilbene acid; 5 , amorfrutin $A ; 6$, longistylin $A ; 7$, longistylin $C ; 8$, cajanstilbene $H$.

of $\mathrm{Zn}$-O bonding), UV-Visible spectral analysis (absorption maximum at $440 \mathrm{~nm}$ ) and TEM analysis (determined size ranging between $40-80$ $\mathrm{nm}$ ). After characterization they determined photocatalytic activity and antimicrobial activity of so synthesized ZnO NPs. ZnO NPs assisted degradation of dye methylene blue (MB) in both sunlight and UV-light were inversely proportional to intensity of light at wavelength $665 \mathrm{~nm}$. Degradation of dye was also found dye concentration and $\mathrm{pH}$ dependent. Higher the dye concentration, lesser is the degradation while at $\mathrm{pH} 10$, degradation is highest $\mathrm{MB}$ is protonated. The antibacterial properties of the $\mathrm{ZnO}$ NPs was screened using agar well diffusion method and broth micro dilution method; against Gram negative bacteria Klebsiella aerogenes, Escherichia coli, Pseudomonas aeruginosa and Gram positive bacteria Staphylococcus aureus. During time of $24 \mathrm{hr}$, free radicals may be generated which might have interacted with bacterial cells and killed them; and thereby exhibited significant antibacterial activity, noted in terms of zone of inhibition. ${ }^{15}$

\section{Titanium dioxide nanoparticles ( $\mathrm{TiO}_{2} \mathrm{NPs}$ )}

In 2019, Arif et al. prepared $\mathrm{TiO}_{2}$ NPs by mixing about $90 \mathrm{ml}$ of $5 \mathrm{mM}$ titanium isopropoxide solution as a precursor with $30 \mathrm{ml}$ of $C$. cajan seed extract as reducing agent in the ratio of 9:3 (v/v) and stirring for $7 \mathrm{hr}$. Then, mixture was centrifuged at 9,000 rpm for 20 min to separate $\mathrm{TiO}_{2}$ NPs which were dried at $100^{\circ} \mathrm{C}$ overnight and followed by calcination at $570^{\circ} \mathrm{C}$ in a muffle furnace for $2.5 \mathrm{hr}$. Then, they studied the interesting application of $\mathrm{TiO}_{2} \mathrm{NPs}$ in controlling the fouling of ultrafiltration PVDF membranes. In Bovine Serum Albumin (BSA) filtration experiment, it was observed that solutes are not deposited into the pores of $\mathrm{TiO}_{2} \mathrm{NPs}$ treated PVDF membranes, which indicates that the fouling process could be made physically reversible. ${ }^{16}$

\section{Gold nanoparticles (Au NPs)}

When gold is fabricated in nanoparticles, it has many unique properties pertaining to localized surface plasmon resonance (LSPR). The gold nanoparticles with different shapes are associated with diagnosis and therapy including cancer treatment, as anti-angiogenesis, antiarthritic, antimalarial agents and many more. Because of their excellent photoelectrochemical and photocatalytic properties that they possesses, Au NPs are used in various devices like photovoltaic cells, photoelectrodes, optoelectronic devices sensors, photocatalysis. ${ }^{17}$

Due to these applications, Ananthi et al. 2017 explored the use of C. cajan leaves in fabrication of Au NPs and their evaluation of antimicrobial efficacy and anti-fouling application on metal coupons. They first prepared aqueous extract of previously sterilised fine powder of C. cajan leaves in Milli Q water and filtered. Then, about $10 \mathrm{ml}$ of extract was mixed with $90 \mathrm{ml}$ of $10^{-3} \mathrm{M}$ gold chloride prepared in Milli Q water. After $24 \mathrm{hr}$, Au NPs were separated by centrifugation and characterised by advanced analytical tools. The Au NPs so synthesised were found capped with compounds having phenolic hydroxyl groups (flavonoids and/or tannins) and have absorption maximum at $540 \mathrm{~nm}$. Presence of gold had been confirmed by EDS analysis while cubic shape and size (1-100 $\mathrm{nm}$ ) were determined by SEM analysis. The ability of these green synthesized Au NPs to control the biofilm forming bacterial communities was determined by conducting the anti-microfouling studies, which indicated that Au NPs inhibit the growth and survival of biofilm forming bacteria effectively on stainless steel -SS304 metal coupons. ${ }^{18}$

\section{CONCLUSION}

Different parts of plant possess different classes of phytochemcials. These can be secondary metabolites like flavonoids, alkaloids, tannins, glycosides, terpenes. These types of phytochemicals are responsible for fabrication of metal and metal oxide nanoparticles. So far, silver, gold, zinc oxide and titanium dioxide nanoparticles have been synthesised using Cajanus cajan extracts and evaluated for different applications like photocatalytic degradation of dye and antimicrobial activity. It can be concluded that, different solvent extracts of different parts of same plant can be made and used for preparation of different nanoparticles which could further be screened for same or other applications.

\section{REFERENCES}

1. Patil SP. Ficus carica assisted green synthesis of metal nanoparticles: A mini review. Biotechnol Rep. 2020;28:e00569.

2. Zhang NL, Zhu YH, Huang RM, Fu MQ, Su ZW, Cai JZ, et al. Two New Stilbenoids from Cajanus cajan. Z Naturforsch. 2012;67(12):1314-8.

3. Zu YG, Fu YJ, Liu W, Hou CL, Kong Y. Simultaneous determination of four flavonoids in pigeonpea Cajanus cajan (L.) Millsp. leaves using RP-LC-DAD. Chromatographia. 2006;63(9-10):499-505.

4. Fu YJ, Zu YG, Liu W, Hou CL, Chen LY, Li SM, et al. Preparative separation of vitexin and isovitexin from pigeonpea extracts with macroporous resins. J Chromatogr A. 2007;1139(2):206-13.

5. FuYJ, LiuW, ZuYG, Tong MH, Li SM, Yan MM, et al. Enzyme assisted extraction of luteolin and apigenin from pigeonpea Cajanus cajan (L.) Millsp. leaves. Food Chem. 2008;111(2):508-12.

6. Wei ZF, Luo M, Zhao CJ, Li CY, Gu CB, Wang W, et al. UV-induced changes of active components and antioxidant activity in postharvest pigeon pea [Cajanus cajan (L.) Millsp.] leaves. J Agric Food Chem. 2013;61(6):1165-71.

7. Wei Z, ZuY, FuY, Wang W, Luo M, Zhao C, et al. lonic liquids-based microwaveassisted extraction of active components from pigeon pea leaves for quantitative analysis. Sep Purif Technol. 2013;102:75-81.

8. Cooksey CJ, Dahiya JS, Garratt PJ, Strange RN. Two novel stilbene-2-carboxylic acid phytoalexins from Cajanus cajan. Phytochemistry. 1982;21(12):2935-8

9. Ajaiyeoba EO, Ogbole OO, Abiodun OO, Ashidi JS, Houghton PJ, Wright CW Cajachalcone: An Antimalarial Compound from Cajanus cajan Leaf Extract. J 
Parasitol Res. 2013

10. Cai JZ, Tang R, Ye GF, Qiu SX, Zhang NL, HuYJ, et al. A Halogen-Containing Stilbene Derivative from the Leaves of Cajanus cajan that Induces Osteogenic Differentiation of Human Mesenchymal Stem Cells. Molecules. 2015;20(6):1083947.

11. Hassan EM, Matloub AA, Aboutabl ME, Ibrahim NA, Mohamed SM. Assessment of anti-inflammatory, antinociceptive, immunomodulatory and antioxidant activities of Cajanus cajan L. seeds cultivated in Egypt and its hytochemical composition. Pharm Biol. 2016;54(8):1380-91.

12. Ogunbinu AO, Flamini G, Cioni PL, Adebayo MA, Ogunwande IA. Constituents of Cajanus cajan (L.) Millsp., Moringa oleifera Lam., Heliotropium indicum L. and Bidens pilosa L. from Nigeria. Nat Prod Commun. 2009;4(4):573-8.

13. Nagati $V$, Koyyati R, Donda MR, Alwala J, Kundle KR, Padigya PRM. Green Synthesis and characterization of Silver nanoparticles from Cajanus cajan leaf extract and its antibacterial activity. International Journal of Nanomaterials and Biostructures. 2012;2(3):39-43.
14. Patil SP, Kumbhar ST. Vitex negundo assisted green synthesis of metallic nanoparticles with different applications: A mini review. Futur J Pharm Sci. 2020;6(1):90

15. Manjunath K, RavishankarTN, Kumar D, Priyanka KP, Varghese T, Naika HR, et al. Facile combustion synthesis of $\mathrm{ZnO}$ nanoparticles using Cajanus cajan (L.) and its multidisciplinary applications. Mater Res Bull. 2014,57:325-34.

16. Arif Z, Sethy NK, Kumari L, Mishra PK, Verma B. Green synthesis of $\mathrm{TiO}_{2}$ nanoparticles using Cajanus cajan extract and their use in controlling the fouling of ultrafiltration PVDF membranes. Korean J Chem Eng. 2019;36(7):1148-56.

17. Yu KF, Kelly KL, Sakai N, Tatsuma T. Morphologies and surface plasmon resonance properties of monodisperse bumpy gold nanoparticles. Langmuir. 2008;24:5849-54

18. Ananthi V, Ahmed JS. Cajanus cajan mediated gold nanoparticle synthesis, characterization, antimicrobial efficacy and its antifouling application on metal coupons. Asian J Pharm Technol Inno. 2017;05(23):41-54.

Article History: Submission Date : 24-12-2021; Revised Date : 18-01-2021; Acceptance Date : 31-01-2021

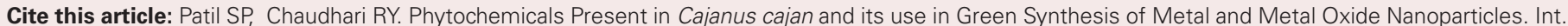
J. Pharm. Investigation. 2021;11(1):1-4 